\title{
Financial Leverage and Profitability among Deposit-Taking Microfinance Institutions in Nairobi City County, Kenya
}

\author{
Christine M. Okumu \\ Ambrose O. Jagongo \\ Department of Accounting and Finance \\ School of Business \\ Kenyatta University
}

\begin{abstract}
Very few deposit-taking microfinance institutions in Kenya are profitable and many of them have collapsed and others have merged to improve in their financial performance. This study investigated the effect of financial leverage on profitability in deposit-taking microfinance institutions in Nairobi City County, Kenya. The specific objectives of the study were the effect of short term debt, long term debt and the equity ratio on profitability in deposit-taking microfinance institutions in Nairobi City County and also to establish the moderating effect of firm size on the relationship between the financial leverage and profitability in deposit-taking microfinance institutions in Nairobi City County. The study was anchored on four theories, namely pecking order theory, agency cost theory, Modigliani and Miller theorem and growth of the firm theory. Furthermore, the study adopted the positivistic approach and a panel regression model was employed to analyze the effects of financial leverage and profitability in deposit-taking microfinance institutions in Nairobi City. The targeted population was 12 deposit-taking microfinance institutions in Nairobi City County. The data was collected for the period between 2014 and 2018. Moreover, the study was conducted a census of all the 12 deposit-taking microfinance institutions in Kenya and the secondary data was used in the study. The data was analyzed using descriptive and inferential statistics. The descriptive statistics was presented in mean, median, standard deviation and frequencies while the inferential statistics included the diagnostics tests, Pearson correlation and multiple linear regression models. The diagnostics tests consisted of panel unit root test, test for fixed or random effects, normality tests, multicollinearity, autocorrelation and heteroscedasticity. The findings of the study showed that short term debt ratio and ROA were positively and significantly associated $(r=0.698, p=0.000)$. Long term debt ratio was positively and significantly associated with $R O A(r=0.578, p=0.000)$.Also, Equity ratio was positively and significantly correlated to ROA $(r=0.588, p=0.000)$.Finally, firm size (log of the total assets) was positively and significantly associated with ROA $(r=0.547, p=0.000)$. Further, short term debt was positively and significantly related with $R O A(\beta=0.860034$, $p=0.000)$. Long term debt was negatively and significantly related to the profitability $(R O A)(\beta-0.12477, p=0.037)$. Additionally, equity ratio was found to be positively and significantly related to $R O A(\beta=0.138056, p=0.000)$. The $R^{2}$ for firm level factors before moderation was $71.42 \%$ but after moderation, the $R^{2}$ increased significantly to $76.62 \%$. This implied that firm size moderate the relationship between financial leverage and profitability of deposit taking microfinance institutions in Nairobi. Moreover, the moderated effect of firm size revealed that there was a positive and significant relationship between short term debt and ROA $(\beta=0.213783, p=0.000)$. Moreover, the results show that moderated effect of firm size revealed that there was a negative and significant relationship between long term debts and ROA $(\beta=-0.105436, p=0.019)$. Likewise, the moderated effect of firm size showed that there was a positive and significant relationship between equity ratio and $R O A(\beta=0.157025, p=0.039)$. The study concluded that short term debt and equity ratio were positively and significantly related to the ROA. While that long term debt was negatively and significantly related to ROA. The study recommended for deposit taking microfinance institutions to use short term debt and equity financing in to finance their assets since it was found to have a positive effect on the profitability of the institutions whereas to keep off from the long term debt since it deteriorates their profits.
\end{abstract}

Keywords: financial leverage, short-term debt, long-term debt, equity ratio and deposit-taking microfinance institutions.

\section{Introduction}

\section{Background of the Study}

Financial leverage is the ratio between the debt and the equity which characterizes the connection between the obtained assets and the assets of the investors in the capital structure (Chadha \& Sharma, 2015). It measures how firms utilize the equity and the borrowed money to finance their operations and generate profits for the company (Chen, Harford \& Kamara, 2019). The higher financial leverage will prompt higher loan costs in the acquisition of the debts, which will prompt a low procuring per share (Rukaria, 2015). According to Richards and van Staden (2015) short term debt, long term debt and equity ratio are the major components of the financial leverage. 
Short term debt typically offers lower interest charges and most lenders do not charge the interest until the stipulated time matures (Mian \& Santos, 2018). Furthermore, long term debt is cash that is owed to loan lenders for more than 12 months and earns more interest (Harford, Kecskés \& Mansi, 2018). Finally, the equity ratio estimates the extent of the all-out resources possessed that are claimed and financed by the partners (Boadi, Dana, Mertens \& Mensah, 2017).

According to Siddik, Kabiraj and Joghee (2017) total debt, particularly the long-term debt, negatively influenced the profitability of banks in Bangladesh. Moreover, Bashir and Asad (2018) uncovered that the board size, board meetings significantly affected the textile performance in Pakistan and the moderating effect of leverage was critical and positive on the connection between board meeting and performance. Also, Bhardwaj (2018) reported debts had a feeble positive relationship with the monetary exhibition in the firms measured by the use of earnings per share in India. Additionally, Shrivastava and Kumar (2017) found an adverse association between the firm size and performance, while the substantial resource quality was noted to affect financial performance positively.

Godswill, Ailemen and Osabohien (2018) reported higher levels of equity positively affected the monetary execution of the business banks in Nigeria. Additionally, Kalu, Shieler and Amu (2018) found microfinance organizations in Uganda financed some of their activities using debts as the financing option and the financial performances improved. Furthermore, Lubawa, Shirima and Nandonde (2018) noted equity financing is a generally less expensive alternative and all things considered improves the exhibition of Micro, Small and Medium Enterprises institutions in Rural Tanzania. Further, Abiodun (2017) noted that the size of the quoted firms in Nigeria positively influenced the leverage ratio.

In Kenya, Muthuri (2018) showed the composition of debts and equity finances being critical in determining the financial stability in the operation of activities and the benefits associated with the financing option. Additionally, Wambua (2018) established that debt emphatically influenced the money related independency and execution. Moreover, Kajiriwa (2015) indicated the long-term deficit in commercial banks affects the capital structure negatively and the high debts become a burden to the firms and the level of the profits is affected adversely. Further, Maura and Oketch (2015) revealed that the debt collection process in the microfinance positively affected the credit risk management, which in return reduced the profitability of the firms.

Additionally, according to Waweru and Wanyoike (2016), equity capital is essential in enhancing the profitability of Micro Finance Institutions and debt capital to have opted as the last financing option for the firms. Furthermore, Amsi, Ngare, Imo and Gachie (2017) showed that value proportion decidedly influenced the monetary exhibition of the Small and Mediums Enterprises business. Finally, Wahome, Memba and Muturi (2015) exhibited progressively unmistakable firms get benefits by their size and improvement since they can get obligations with lower costs and persevere through money related failures with more adaptability than smaller firms and along these lines produce more advantage.

\section{Financial Leverage}

Financial leverage describes the companies' business structure and reveals the equilibrium between two long term finance sources (Andrew, 2015). When the firms borrow, the difference between directors and creditors increases the control costs, so the firms disclose more information to convince the shareholders and creditors to decrease the control costs (Chesang, 2017). Adams and Ferreira (2016) discovered that large firms have the tendencies of disclosing their information to their shareholders contrasted with the little firms. Most likely it will comprehend the potential favorable circumstances of information exposure, for example, more prominent attractiveness and more prominent simplicity of financing. Smaller companies may feel that full data revelation may jeopardize their focused position (Barako, Hancock \& Izan, 2016).

Leverage has been recognized as the most vital element when making any of the decisions related to the financing options in a company. More profits are realized by the companies when they have a higher debt to the equity levels (Watts \& Zimmerman, 2018). Graham, Harvey and Puri (2017) found that that organization that has increased in the maximizing in borrowing has a higher chance to continue making profits. Alsaeed (2016) contended that organizations with relatively more substantial measures of obligation in their capital structure are slanted to higher office costs. Therefore, directors have a motivating force to lessen these office costs and maximize the returns within an organization by wisely examining the best financing options available.

\section{Short term debt}

As indicated by Mulyono, Djumahir and Ratnawati (2018), Short term debt financing has a maturity time of one year or less and should be repaid within four months. Further, the short-term loans have a low-interest rate and the companies prefer it when looking forward to having short term financing (Yazdanfar \& Öhman, 2015). Additionally, according to Mian and Santos (2018), the short-term debts help to address the quick issue for financing without long term responsibility. The cost of changing short term obligation is less load on the 
association. Short term advances generally offer lower interest charges, and most loan lenders do not charge interest until all credit remittance period is over (Kahl, Shivdasani \& Wang, 2015).

Money related choices of transient obligations and liabilities are basic since they set up the money related relentlessness of the firm in the market (Godswill, Ailemen \& Osabohien, 2018). Short term debt has been found by various scholars and researchers to affect profitability. Aro and Pennanen (2017) found that firms can make use of short-term financing, which may affect the profitability depending on the cost of the source of the funding. Bendavid, Herer and Yücesan (2017) observed that firms might have a specific ration of short-term liabilities if its financing structure they feel is optimum in enhancing performance and profitability. Dombret, Gündüz and Rocholl (2019) observed that firms which had high short term debt levels when compared to their long term debt performed better than their competitors

Kumar and Kaushal (2017) established that the use of short-term liabilities such as trade payables and accruals could have a positive effect to the productivity of the organizations since such sources of financing may be less costly to the business than the longer-term sources of funds. Further, short term sources of funds may have a positive influence on profitability due to the reduced contractual engagements that are involved. Furthermore, Nawaz and Ahmad (2017) claimed that the short maturity of short term debt might be expensive to the firm hence increasing its cost of capital.

\section{Long term}

Long term debt involves an agreement between the firm and issuers of debt, which is usually associated with high agency and financial distress costs (Chavali \& Rosario, 2018). High long-term debt levels in the firm are not conducive for the effective operations of the firm since they increase the risk of bankruptcy and the interests associated with them is high. According to Harford, Kecskés and Mansi (2018) high debt levels increase the number of interest payments that are expected to be paid regularly which may undermine the liquidity levels of the company thus lead the company into financial problems.

Moreover, the examination by Pontoh (2017) found no considerable connection between long term obligation and benefit in the organizations. Long term debts are best and reliable avenues for debt financing in most of the established business (Foyeke, Olusola \& Aderemi, 2016). Furthermore, Nunes and Serrasqueiro, (2017) argued that long term debt could be decidedly identified with the development/share/deals adequacy and gross benefit in little and medium-size assembling firms.

\section{Equity Ratio}

The equity ratio is a better indicator of the level of the leverage that is being used in the company. A high equity ratio produces a bad result for the company while a low equity ratio produces best results to the shareholders as much as the company earns a specified rate of returns on the assets and is higher than the interest rates that are being paid to the creditors (Chadha \& Sharma, 2015). Equity financing is the financing source a company prefers the least and is only used when the debt capacity has reached to the optimal and the company lacks an alternative method to finance its activities. In the time the company uses this option, the decision-makers in the organization believe that the market valuates the company too high because of the data asymmetry in the company to the external investors (Boadi, Dana, Mertens \& Mensah, 2017).

The company will have to use several approaches to raise funds to achieve the necessary capital mix with the adequate sources being held as the retained earnings of the business, debt and the equity (Cole, Yan \& Hemley, 2015). Mule and Mukras (2015) established the sources of the capital for firms as being either internally or externally sourced. The internal financing is the one that is coming from the retained earnings while the external gains come from the debts and the issue of the equity. The financial leverage is very critical to any of the organizations since they define the financial stability of the organization. Capital structure decisions are significant as the focal in determining the business entity in choosing between financing alternatives at the maximum costs that yield to the total value of the firm. Moreover, Das and Swain (2018) established that various strategies could be connected by the association to raise the capital with the most fundamental and crucial sources being retained earnings, equity and debt.

\section{Firm Size}

Firm size alludes to how little or enormous a firm is through the estimation by capital, the number of employees, markets share resource and the chance to acquire outside financing and information level influencing the firm for the inclination of financing sources (Tita, 2016). This situation furnishes organizations with a chance to work in higher benefit conditions with less challenge (Nawaiseh, 2015). Smaller firms have high liquid assets and are thought to have more financial capabilities than larger organizations in the short term (Muigai, 2016). Moreover, more significant organizations can minimize information asymmetry in the market and acquire financial resources efficiently. They can also access debt easily when good risk profiles are maintained as opposed to small organizations due to stability (Bongoye, Banafa \& Kingi, 2016). 
Organization's size is seen by assembling organizations as an asset in acquiring an economic upper hand in terms of benefit and market share of the overall industry (Abbasi \& Malik, 2015). Firm size can either be estimated by the level of benefits or greatness of offers. The exchange off theory recommends that more significant firms ought to work at high debt levels because of their capacity to differentiate the hazard and to take advantage of assessment shields on interest installments (Chesang, 2017). Larger firms typically are increasingly broadened and have lower fluctuation in income and consequently can suit high debt ratios. Littler firms then again may discover it generally costlier to join debt in their operation. In this way, more prominent firms will have higher debt levels than littler firms (Pantouvakis, Vlachos \& Zervopoulos, 2017).

\section{Profitability}

Profitability is the difference in the total revenue and the total cost and the higher the distinction, the better the presentation of an organization. The primary source of the returns of the financial institutions is issuing of the loans, which generates some interests (Chikalipah, 2018). According to Mwai (2018), Low profitability debilitates the limit of Deposit taking MFIs to retain negative stuns, which in this manner influence their dissolvability. The profitability of MFIs is determined by how they are run given their location of operations, nature of their administration and levels of capitalization. According to Abubakar (2015), the profitability of a company is having the ability to make sales and realizes a profit from any business activities of the firm. It measures the efficiency of the management in the utilization of the available resources in the process of adding value to an organization (Muriu, 2016). The profitability levels may be regarded as a relative term that is measurable in forms of the profit and its realization with other elements that has a positive effect to influence the benefits.

According to Gweji and Karanja (2014), the profit maximization is the main objectives of the business entities and each firm has to be making profits to remain relevant and be in a position to compete healthy/. Increasing the profitability rations involves the company looking into areas that are working better and also the areas that are not working right for them. Siddik, Kabiraj and Joghee (2017) found that profitability is the last measurement of the monetary achievement and disappointment of an organization. This study used profit after tax (net profits) and ROA to measure profitability as used in the studies of (Abubakar 2015; Siddik, Kabiraj \& Joghee, 2017).

\section{Deposit-Taking Microfinance Institutions}

Microfinance institutions are significant in poverty reduction in the World. They focus on the poor through different ways such as group loaning, individual loaning and insurance substitutes. Moreover, most of the Microfinance contribute mainly to the process of arrangement of money related administrations to poor families who do not have an arranged access to formal financial establishments. There are 13 microfinance banks in the country, but only 12 are found in Nairobi County. They incorporate three-level one microfinance banks (Kenya Women Presently Echo Network Africa, Faulu and Rafiki) (Ali, 2015). The three medium microfinance banks had a share of the overall industry of 6.6 percent (SMEP, Caritas and Sumac) and seven little microfinance banks (Remu, Uwezo, U\&I, Century, Daraja, Maisha) had a share of the overall industry of 3.4 percent. The list of the 12 institutions is shown in Appendix 1. The DTMs have added to the extending of money related incorporation by opening branches in numerous parts of Kenya and the district (Belydah \& herick, 2017). They have additionally grown new money related items that are request-driven and that are proper to the requirements of the customers.

Microfinance is very critical in the poverty eradication in many states of the World. They are widely known to target the poor and the marginalized groups by use of innovative approaches such as joint lending, progressive lending and regular payment. It majorly focuses on the women and the poor (Wijesiri \& Meoli, 2015). The general concept of the microfinance institutions can be traced down from early $1700 \mathrm{~s}$ through the work of an Irishman, Jonathan Swift, who facilitated the creation of a bank to the poor in rural areas in Ireland (Rade, 2016). In Canada and United States, the microfinance organizations mostly target the less fortunate and marginalized populations who are not in a position to access to the commercial banks and a close of eight percent of the Americans are not banked (Nyaga, 2017).

As an industry, microfinance is another current phenomenon in Kenya and began to gain the momentum to compete with the established financial institutions (Ali, 2015). Difficult to access to the credit was considered to be a significant setback for the entrepreneurial development and thus the Kenya Rural Enterprise Programme (KREP) can be viewed as the pioneer of the Non-Governmental microfinance in Kenya (Wijesiri \& Meoli, 2015). Therefore, KREP was designed and mandated as an intermediary NGO in the year 1984 to give credit and specialized help to different NGOs working in Kenya (Ayele, 2015). Numerous establishments, for example, companies, cooperatives societies, trusts, NGOs, informal sectors and the state corporations carry out the microfinance in Kenya. Moreover, Kenya in the past has been exposed to very many microfinances than any other state in Sub-Saharan Africa, with the micro-financing activities dating back the early 1980s (King'ori, Kook \& Shikumo, 2017). 


\section{Statement of the Problem}

According to Diar, Rotich and Namburi (2017), some microfinance institutions fails to utilize well the available assets to become sustainable thus enter to the liquidity problems. One of the most critical roles of the financial managers in any of the organization is to formulate monetary policies that amplify the benefit of the organization among them being the financial influence choice (Mueni \& Muturi, 2015). However, because of constrained accessibility of organization assets, financial managers need to endeavor to guarantee appropriate working capital to evade the open-door cost of previous assets held in current resources, henceforth bringing down the company's profits (Mwangi, Muturi \& Ombuki, 2015). Throughout the world, the performance of deposit-taking microfinance institutions has been one of the issues that have, as of late caught the consideration of numerous analysts and researchers.

Ochieng (2018) revealed that very few Deposit Taking Microfinance Institutions are profitable in Kenya due to financial constraints. Additionally, Mwangi, Muturi and Ombuki (2015) discovered that a considerable lot of the deposit taking microfinance establishments are unsustainable, many fallen, and others consolidated while others were non-performing. The choice to utilize both debts and value accompanies costs while depending on obligations just prompts cost reserve funds since obligation intrigue is charge deductible, along these lines decreasing the general expense of capital (Ochieng, 2018).

Nevertheless, past investigations conducted to decide the impact of money related influence on stability on the deposit-taking microfinance institutions used large and well-established MFIs in different countries and each study draw its conclusion and none of them came to a unanimous conclusion (Mutethia, 2017; Rukaria, 2015; Barako, Hancock \& Izan, 2016; Alsaeed, 2016). For instance, Bashir and Asad (2018) present conceptual, contextual and geographical gap with the current study. The examination was done in the textile firms in Pakistan and the particular goals of the investigation were the impact of board size, executive gatherings and the directing impact of influence on execution while the particular objectives of the current study is to explore the impact short term obligation, long term obligation and equity ratiomoderating impact of firm size.

Additionally, Godswill, Ailemen and Osabohien (2018) present a contextual gap and conceptual gap with the current study. This is because Godswill, Ailemen and Osabohien (2018) conducted the research in the bank sector and the target of the examination was to inspect the impact of working capital administration and bank execution in Nigeria while the point of the present investigation researched the effect of financial leverage on profitability.

Further, Wambua (2018) on the impact of capital structure on the financial supportability of deposit taking microfinance organizations in Kenya introduces a methodological gap. The study adopted an empirical survey as the research design while the current study will utilize the descriptive research design. Accordingly, the present study may bridge the existing gaps by exploring the influence financial leverage on profitability of the deposit taking institutions in Nairobi.

\section{Objective of the Study}

The general objective of the study is to investigate the effect of financial leverage and profitability among deposittaking microfinance institutions in Nairobi City County, Kenya. The specific objectives of the study were: to establish the effect of short term debt on profitability among deposit-taking microfinance institutions in Nairobi City County; to determine the effect of long term debt on profitability among deposit-taking microfinance institutions in Nairobi City County; to determine the effect of equity ratio on profitability among deposit-taking microfinance institutions in Nairobi City County; to establish the moderating effect of firm size on the relationship between the financial leverage and profitability among deposit-taking microfinance institutions in Nairobi City County.

\section{Scope of the Study}

The research seeks to establish the effect of financial leverage and profitability in deposit-taking microfinance institutions in Nairobi City County, Kenya. The study focused to develop the impact of short term debt on profitability in deposit-taking microfinance institutions in Nairobi City County, determine the effect of long term debt on profitability in deposit-taking microfinance institutions in Nairobi City County, define the impact of equity ratio on profitability in deposit-taking microfinance institutions in Nairobi City County and finally, to establish the moderating effect of firm size on the relationship between the financial leverage and profitability in deposit-taking microfinance institutions in Nairobi City County. The targeted population was 12 deposit-taking microfinance institutions in Nairobi City County. Moreover, the study used secondary data from the published financial statements from the microfinance institutions in Kenya for the period 2014-2018.

\subsection{LITERATURE REVIEW}

\subsubsection{Theoretical Review}




\section{Pecking Order Theory}

This Pecking Order Theory was developed by Myers and Majluf (1984), which proposes that the expense of financing increments with awry information. The theory states that managers of companies follow a specific hierarchy when considering the sources of financing for the company. The firm prioritizes their sources of funding in connection with the rule of the least exertion, which prefers to raise the equity as methods for the final resort. When the companies are faced with no alternative option in the internal financing of the business other than the external funding, then the most priority will borrow through the debt issue since its less risky (Allini, Rakha, McMillan\& Caldarelli, 2018).

Moreover, the pecking order theory acknowledges that there is no target Capital structure. The organizations pick the degree of the capitals as per inside account, obligation, and value. The root of pecking order theory is from the enlightening asymmetry where chiefs find out about an associations prospect than the external lenders. The theory proposes that if the value of the firm issues offers to back an endeavor, it needs to issue shares at not precisely the general market cost. This flag the offers are exaggerated and the administration isn't sure to serve the debt if the task is financed by debt pecking theory is very relevant to many businesses and allows for the dynamics of most of the firms to find out the best capital structure at a particular point (Copeland \& Weston, 1988). The most profitable business in the World has a very low debt to value proportion and furthermore, the less beneficial firm in a similar industry will probably have a high obligation to-value proportion. Pecking order theory clarifies these watched and detailed administrative activities that are supposed to be taken seriously to improve in the performance. It additionally discloses securities exchange responses to use expanding and influence diminishing occasion in the market. (Serrasqueiro \& Caetano, 2015).

However, the pecking order theory does not well illustrate the role of government intervention in the business. The effects of taxation, the financial shocks, the costs of issuance of the security and the arrangement of the venture's chances accessible to the business unit with the actual capital structure (Bhama, Jain, \& Yadav, 2016). Moreover, the theory ignores the challenges that can emerge because of the administrators of the organizations collecting so much money related to leeway that they become resistant to the market discipline. In this way, the pecking order theory is offered as a supplement to, instead of substitution for, the conventional exchange off the model. The theory mostly concentrated on the advantages of the internal financing of the business as opposed to the external sources (Allini, Rakha, McMillan, \& Caldarelli, 2018).

The theory supports the variable equity ratio by hypothesizing that companies are faced with no alternative option in the internal financing of the business other than the external funding, then the most priority is borrowing through the debt issue since its less risky.

\section{Agency Cost Theory}

Agency cost theory was spearheaded out by Jensen and Meckling (1976). The theory establishes choices affecting the execution of the duties in a company are generally made by the management. The theory argues that with minimal supervision, the directors may choose to put resources into activities with negative net value (Bosse \& Phillips,2016). Further, more elevated amount of debt expands investors' worth on account of its disciplinary impact on administrator conduct. The agency theory contends that when ownership and control in an organization are separate, the managers may act out of self-interest and are self-centered, thereby, giving less attention to shareholders' interests (Shi, Connelly \& Hoskisson, 2017). The separation of power and control in an organization may bring about supervisors seeking after various targets other than that of the firm, for example, perquisites, picking information sources or yields that their inclinations, or otherwise neglecting to amplify firm worth.

Substantially, the agency cost of outside proprietorship equivalent to the lost an incentive from expert supervisors boosting their very own utility, rather than the estimation of the firm (Pouryousefi and Frooman, 2017). More prominent financial leverage may influence directors and diminish agency costs through the risk of liquidation, which makes individual misfortunes administrators of pay rates, notoriety, perquisites and additionally through a strain to produce income to pay interest cost (Dawar, 2016). The agency cost hypothesis contends that exceptionally leveraged firms can diminish the agency cost of outside equity and improves the association's presentation, which adequately builds firm worth. Myers (1977) sees that exceptionally leveraged firms can relieve clashes among investors and supervisors concerning the decision of venture. It places that the determination of capital structure helps in moderating agency costs and thereby impacts fast execution (Parker, Dressel, Chevers and Zeppetella, 2018).

In spite of the agency theory being immensely known to business and immensely being reliable to the organizations, it faces criticism from the scholars. For instance, Eisenhardt (1989), Shleifer and Vishny (1997) and Daily et al. (2003) (Panda and Leepsa, 2017). The theory expects a sound understanding between the head and operator for a restricted or the boundless future period, and what's to come is unsure. Besides, the theory accepts that contracting can wipe out the agency issue, however for all intents and purposes, it faces numerous deterrents like data asymmetry, rationality, misrepresentation and exchange cost. The enthusiasm of the Investors' in the firm 
is to extend the benefits; in any case, their activity is obliged in the firm. The responsibilities of managers are just compelled to the administration, and their further job is not unmistakably characterized. The theory considers the administrators as astute and disregards the ability of the directors (Gong, Tang, Liu \& Li, 2017).

Much as this theory affects leverage decisions that need to be taken to address agency conflict arising, it also helps in explaining the role played by top managerial staff in checking the specialists (directors) of the firm. The senior administrative staff as a governance mechanism helps in keeping on toes the managers who pursue self-interest at the expense of shareholder's wealth maximization objective. The board of director will effectively provide an oversight authority to guarantee that the interests of investors are not infringed by managers who are internal players in the firm they are serving. Hence the more significant the board sizes, the effective the monitoring role it is having over the agents. This theory supports the variable short-term debt by positing that highly leveraged firms can reduce the agency cost of outside equity and improves the firm's performance, which effectively increases firm value.

\section{Modigliani and Miller theorem}

Modigliani and Miller (1958) first established that there is no relationship between influence and firm worth. Regardless, in 1963, after they took the impact of expense on firm an incentive into consideration, they reexamined this supposition and expressed that issuing debt can build firm esteem (Myers, 2001). The theory depended on the contention that the utilization of debt offers an assessment shield. Because of this declaration, firms could pick all the obligations as the capital structure. In any case, argued that the MM model is genuine just in theory because and by liquidation costs exist and will even increment when equity is exchanged off for debt (Gómez, Castro \& Ortega, 2016). Furthermore, the estimation of the firm would increase the expense of capital to lessen the use of the debts in light of evaluation deductibility of intrigue charges (Ahmeti \& Prenaj, 2015). This way, the estimation of the organization can be practiced by boosting the obligation fragment in the capital structure. Moreover, considering the financial constraints, DeAngelo and Masulis (1980) expressed that the parity of benefits and costs will prompt ideal leverage. The advantages of issuing debt originate from both assessment shield and non-charge shield impacts.

The previous is the expense sparing strength of the interest on the debt, while the last is the decline in assessment getting from nondebt related components, for example, deterioration and venture duty credit (Charness \& Neugebauer, 2019). The higher an organizations leverage is, the higher the cost, and in this manner loan bosses will charge a higher interest rate. Besides, the hazard for a loan boss is generally high in this circumstance, which will prompt agency issues. At the point when a company's leverage stays at a low level, the assessment shield advantages will outperform the cost, yet as the debt rises, the value will likewise quickly increment.

In spite of the Modigliani-Miller theorems being the establishment of an account, the theory experienced analysis, various researchers. Initially, the approach expected that ideal capital markets don't exist because charges are engaged with the capital markets. Additionally, Brigham and Gapenski (1996) concurred that the MM model is genuine just in theory on the grounds that, by and by, chapter 11 costs exist and will even increment when equity is exchanged off for debt (Gómez, Castro and Ortega, 2016). Besides, the theory accepts that profits don't influence the investor's riches and finally the presumption of vulnerability is unreasonable in reality and therefore the theory experiences a few holes that were not tended to (Knoll, 2018). This theory underpins the variable long-term debt by proposing that debt offers a tax shield.

\section{Growth of the Firm Theory}

This theory was initiated by Penrose (1959) who provided trustworthy models regulating the improvement of firms and the rate at which firms can wind up productive and be helpful. Penrose (1959) gives a theory of the fantastic organization of the organization's advantages, advantageous possibilities, and widening system. Specifically, Penrose (1959) provides a useful method of reasoning to unravel causal associations among resources, limits, and high ground, which adds to an advantage-based theory of power. Penrose (1959) gives at any rate three fundamental conflicts concerning linkages among the organization's strengths, advantageous possibilities, and beneficial firm advancement.

Penrose (1959) first keeps up that organizations can profit worth, not due to unimportant responsibility for; in any case, given the ground-breaking and innovative organization of benefits. This exhibits a firm with immense resources is more gainful than a firm with limited resources. Creative resource arrangements of action spur differentiate in beneficial possibilities and cash related execution. Penrose (1959) also gives causal associations among resources and the period of accessible open entryways for improvement and development. Besides, the theory reinforces the variable of firm size by recommending that firm all the more coordinating tremendous resources is for the most part much beneficial than firm telling little resources and can approach gigantic proportion of acknowledge from the moneylenders because of security attached to the organizations. 


\subsubsection{Empirical Review}

Muthuri (2018) examined the impact of monetary stability on the Financial Performance of Commercial Banks in Kenya. The examination found a positive relationship existed between financial execution and performance. The assessment, likewise, established the composition of debts and equity funds are fundamental in deciding the profitability and adjusting the cost of operation of activities and the points of interest related with the financing option gotten by the organization. The study was restricted to the commercial banks in Kenya therefore a contextual gap existed. The current study focused on Deposit-Taking Microfinance Institutions.

Amsi, Ngare, Imo and Gachie (2017) investigated the Effect of microfinance credit on Small and Mediums Enterprises financial performance in Kenya. The results of the study indicated that the equity ratio positively affected the financial performance of the Small and Mediums Enterprises financial institutions. Lenders were more confident to lend out money to big institutions with massive resources as they know they will be repaid on the stipulated time. The study employed a descriptive survey and cross-sectional design. Moreover, the study variables used were: credit amount, collateral requirement, credit repayment and the interest rate on performance. A methodological and conceptual gap existed. The current study adopted a descriptive research design. The variable under study were short term debts, long term debts and equity ratio on the profitability of deposit-taking microfinance institutions.

Hossain and Azam (2016) conducted a study in Bangladesh on the Financial Sustainability of Microfinance Institutions. The findings of the study discovered that the proportion of capital resources, discount and working cost proportion impact enormously the money related supportability of microfinance organizations in Bangladesh. Nonetheless, the obligation value proportion and the outstanding credit to add up to resources and the level of borrowers had no huge effect on the money related supportability of MFIs in Bangladesh during the time of the investigation. The study focused on the capital assets, write-off and operating expense ratio as the study variables. The study thus created a conceptual and geographical gap. The current study focused on Deposit-Taking Microfinance.

Muchiri, Muturi, and Ngumi (2016) investigated the relationship between financial structure and monetary execution of firms at East Africa Securities Exchanges. The data were obtained from 63 firms and the period of the study covered between 2006 and 2014. Data was analyzed using SPSS and STATA. The discoveries of the examination built up that the development of the debt decidedly improve the performance prompting an expansion in the degree of the profit level. The study likewise demonstrated that debt and income are increasingly critical in foreseeing the financial performance of the firms. The study used non-financial institutions in East Africa. Moreover, the study employed an explanatory research design. A methodological, geographical and contextual gap existed. The current study adopted a descriptive research design.

Waweru and Wanyoike (2016) investigated the impact of capital structure on the productivity of microfinance foundations in Nakuru town, Kenya. The investigation embraced a cross-sectional overview research plan. The study concluded that the equity capital ratio in the Microfinance Institutions was on the rise and equity financing was cheaper than other forms of funding in the firm. The study further found that equity capital was necessary for enhancing the profitability of Micro Finance Institutions and the debt capital was the last financing option for the firm. It was further noted that the use of debt capital primarily enhanced profitability in the Micro Finance Institutions. The current study used a descriptive research design.

Kajiriwa (2015) conducted a study on the impact of debts on the fast execution of business banks recorded on the Nairobi Securities Exchange. The examination studied business banks registered on the Nairobi Securities Exchange. The study adopted a longitudinal research design. The discoveries of the investigation found that the long term debt in business banks influences the capital structure negatively. High debts become a burden to the firms and the level of the profits is affected adversely. The current study used Deposit-Taking Microfinance and the descriptive research design was utilized.

\subsection{Research Methodology}

The study adopted the positivistic approach and a panel regression model was employed to analyze the effects of financial leverage and profitability in deposit-taking microfinance institutions in Nairobi City. The targeted population was 12 deposit-taking microfinance institutions in Nairobi City County. The data was collected for the period between 2014 and 2018. Moreover, the study was conducted a census of all the 12 deposit-taking microfinance institutions in Kenya and the secondary data was used in the study. The data was analyzed using descriptive and inferential statistics. The descriptive statistics was presented in mean, median, standard deviation and frequencies while the inferential statistics included the diagnostics tests, Pearson correlation and multiple linear regression models. The diagnostics tests consisted of panel unit root test, test for fixed or random effects, normality tests, multicollinearity, autocorrelation and heteroscedasticity. The study employed the following empirical Model Yit $=\beta_{0}+\beta$ Xit $+\varepsilon i t$. 3.1 
Where Yit is the dependent variable denoting profitability in deposit-taking microfinance institutions $i$ at time $t, i$ mean the observation (deposit-taking microfinance institutions), $\mathrm{i}=1, \ldots \ldots ., 12$ while $\mathrm{t}$ is the period $\mathrm{t}=2014, \ldots$, 2018; Xit denotes a vector of independent variables indicating financial leverage, $\beta$ are coefficients to be estimated, $\beta_{\mathrm{o}}$ is a constant term, and $\varepsilon$ it is composite error term. The study will use a panel data model because it can be used to study more complex data involving several parameters.

\section{Regression Model}

Yit $=\beta 0+\beta 1 \mathrm{X} 1$ it $* \mathrm{M}+\beta 2 \mathrm{X} 2 \mathrm{it} * \mathrm{M}+\beta 3 \mathrm{X} 3 \mathrm{it} * \mathrm{M}+\varepsilon$ it

Where;

Yit= Profitability for firm $i$ at time $t$

$\mathrm{X} 1 \mathrm{it}=$ Short term debt for firm $\mathrm{i}$ at time $\mathrm{t}$

$\mathrm{X} 2 \mathrm{it}=$ Long term debt for firm $\mathrm{i}$ at time $\mathrm{t}$

$\mathrm{X} 3 \mathrm{it}=$ Equity ratio for firm $\mathrm{i}$ at time $\mathrm{t}$

$\mathrm{M}=$ Firm size for firm $\mathrm{i}$ at time $\mathrm{t}$

$\beta 0=$ Constant, $\beta 1 \ldots 4=$ Coefficient of the variables

$\varepsilon$ it $=$ Error term

\subsection{Results and Discussions}

\subsection{Descriptive Statistics}

This part displays the clear outcomes for the factors. Clear measurements utilized were mean, minimum, maximum and standard deviation. The outcomes are displayed in Table 4.1

Table 4.1 Descriptive Statistics

\begin{tabular}{llllll}
\hline Variable & $\mathrm{N}$ & Mean & Std. Deviation & Minimum & Maximum \\
\hline ROA & 60 & 0.293768 & 0.260614 & 0.0103 & 0.8887 \\
Short term debt ratio & 60 & 0.293593 & 0.189429 & 0.0278 & 1.0000 \\
Long term debt ratio & 60 & 0.166582 & 0.185557 & 0.0089 & 1.0000 \\
Equity Ratio & 60 & 0.25979 & 0.187533 & 0.0050 & 1.0000 \\
Log of Total Assets & 60 & 1.742608 & 1.053743 & 0.1257 & 3.5072 \\
\hline
\end{tabular}

The results from Table 4.1 shows that the mean of profitability of the deposit microfinance institutions predicted using ROA was 0.293768 which shows that the general performance of the deposit taking micro finance institution. The minimum and the maximum of return on assets were 0.0103 and 0.8887 respectively. Its standard deviation (SD) was 0.260614 which showed that profitability changed during the period. The outcome is consistent with the findings of Bashir and Asad (2018) who found that size of a firm has the potential to influence the firm's financial performance in terms of the choice of capital structure mix and the profitability changes over time depending on the capital structure employed. Moreover; short term debt ratio had a mean of 0.293593 . The maximum and the minimum of short term debt ratio was 0.0278 and 1.0000 respectively. The standard deviation was 0.189429 . This means that short debt ratio keeps on changing during the time of study.

Also, long term debt ratio had a mean of 0.166582 . The maximum and the minimum were 0.0089 and 1.000 respectively. The standard deviation was 0.185557 . This implied that the long term debt ratio kept on changing during the period under study. The results concur with the findings of Muchiri, Muturi, and Ngumi (2016) that established growth of the debt positively improve the performance leading to an increase in the level of the profit level. The study also indicated that debt and retained earnings are more significant in predicting the financial performance of the firms and they keep changing over time.

The mean for equity ratio was 0.25979 . Further the maximum and minimum of equity ratio was 0.0050 and 1.0000 respectively. Its Standard deviation was 0.187533 indicating that equity ratio changes over the period of the study. Finally, log of the total assets (firm size) has a mean of 1.742608 . The maximum and the minimum of the log of total assets was 0.1257 and 3.5072. Additionally, the standard deviation was 0.1257 . This implied that the sizes of the firms changed during the period that was used to conduct the study. The results concur with the findings of Abiodun (2017) that revealed size of the firm has a positive influence on the leverage ratio of the listed firms in Nigeria.

\subsection{Correlation Analysis}

Correlation analysis predicts the association between research variables. Correlation table was employed to establish the association between variables. Table 4.2 shows the findings of the correlation matrix. 
Table 4.2 Correlation Analysis

\begin{tabular}{|c|c|c|c|c|c|c|}
\hline & & ROA & $\begin{array}{l}\text { Short term debt } \\
\text { ratio }\end{array}$ & $\begin{array}{l}\text { Long term debt } \\
\text { ratio }\end{array}$ & $\begin{array}{l}\text { Equity } \\
\text { Ratio }\end{array}$ & $\begin{array}{l}\text { Log of Total } \\
\text { Assets }\end{array}$ \\
\hline ROA & $\begin{array}{l}\text { Pearson } \\
\text { Correlation }\end{array}$ & 1.000 & & & & \\
\hline $\begin{array}{l}\text { Short term } \\
\text { debt ratio }\end{array}$ & $\begin{array}{l}\text { Sig. (2-tailed) } \\
\text { Pearson } \\
\text { Correlation }\end{array}$ & $.698 * *$ & 1.000 & & & \\
\hline $\begin{array}{l}\text { Long term debt } \\
\text { ratio }\end{array}$ & $\begin{array}{l}\text { Sig. (2-tailed) } \\
\text { Pearson } \\
\text { Correlation }\end{array}$ & $\begin{array}{l}0.000 \\
.578 * *\end{array}$ & $.578 * *$ & 1.000 & & \\
\hline & $\begin{array}{l}\text { Sig. (2-tailed) } \\
\text { Pearson }\end{array}$ & 0.000 & 0.000 & & & \\
\hline Equity Ratio & Correlation & $.558 * *$ & $.581 * *$ & $.452 * *$ & 1.000 & \\
\hline $\begin{array}{l}\text { Log of Total } \\
\text { Assets }\end{array}$ & $\begin{array}{l}\text { Sig. (2-tailed) } \\
\text { Pearson } \\
\text { Correlation } \\
\text { Sig. (2-tailed) }\end{array}$ & $\begin{array}{l}.547 * * \\
0.000\end{array}$ & $\begin{array}{l}.348^{* *} \\
0.006\end{array}$ & $\begin{array}{l}0.000 \\
0.05 \\
0.702\end{array}$ & $\begin{array}{l}.328 * * \\
0.01\end{array}$ & 1.000 \\
\hline
\end{tabular}

The results from Table 4.2 show that short term debt ratio and return on assets are positively and significantly associated $(\mathrm{r}=0.698, \mathrm{p}=0.000)$. Long term debt ratio was positively and significantly associated $(\mathrm{r}=0.578, \mathrm{p}=0.000)$. Also, Equity ratio was positively and significantly correlated to the return on assets $(r=0.588, p=0.000)$. Finally, firm size (log of the total assets) was positively and significantly associated with the return on assets ( $r=0.547$, $\mathrm{p}=0.000$ ). The findings of the results concur with the results of Wambua (2018) that found that debt had a positive and significant association on the financial sustainability of Deposit Taking Microfinance in Kenya and thus the financial sustainability would increase with a proportionate increase in debt when all other factors affecting the profitability of the organizations are held constant. Also, Amsi, Ngare, Imo and Gachie (2017) indicated that the equity ratio positively and significantly associated with the financial performance the financial performance of the Small and Mediums Enterprises.

\subsection{Diagnostics Tests}

\subsubsection{Normality Test}

Normality test was tested using skewness and Kurtosis test. The test statistic was that if the p value $>0.05$, the study conclude that the data is normal. Table 4.3 presents the normality test

Table 4.3 Normality Test

\begin{tabular}{llllll}
\hline Variable & Obs & Pr(Skewness) & Pr(Kurtosis) & adj chi2(2) & Prob>chi2 \\
\hline ROA & 60 & 0.0062 & 0.5498 & 7.08 & 0.1289 \\
Short term debt ratio & 60 & 0.0676 & 0.7518 & 3.61 & 0.1643 \\
Long term debt ratio & 60 & 0.0023 & 0.7335 & 8.21 & 0.3165 \\
Equity Ratio & 60 & 0.1148 & 0.8503 & 2.64 & 0.2671 \\
Log of Total Assets & 60 & 0.0206 & 0.0533 & 7.99 & 0.1184 \\
\hline
\end{tabular}

The results from Table 4.3 shows that the data was normally distributed as the respective $\mathrm{p}$ values for all variables were greater than 0.05 .

\subsubsection{Multicollinearity Test}

Multicollinearity was assessed in this study using the variance inflation factors (VIF). According to Katrutsa and Strijov (2017) VIF values in excess of 10 is an indication of the presence of Multicollinearity. Multicollinearity inflates the standard errors and confidence intervals leading to unstable estimates of the coefficients for individual predictors. Table 4.4 presents the multicollinearity result 
Table 4.4: Multicollinearity Test

\begin{tabular}{ll}
\hline Variable | & VIF \\
\hline Short term debts ratio & 1.44 \\
Long term debts ratio & 1.22 \\
Equity Ratio & 2.5 \\
Log of Total Assets & 2.21 \\
Mean VIF & 1.84 \\
\hline
\end{tabular}

The results in Table 4.4 indicated absence of multicollinearity since the VIF of all the variables were less than 10 .

\subsubsection{Autocorrelation Test}

The study employed the Wooldridge test for autocorrelation to detect the existence of autocorrelation in the data, that is, whether or not the residual is serially correlated over time and the results are shown in Table 4.5.

\section{Table 4.5 Autocorrelation Test}

\section{Wooldridge test for autocorrelation in panel data}

H0: no first-order autocorrelation

$\mathrm{F}(1,11)=83.640$

Prob $>\mathrm{F}=0.1000$

The null hypothesis of this test was that there is no first order serial/autocorrelation existed in the data. From the results in Table 4.5, the test statistic reported is F-test with one and eleven degrees of freedom and a value of 83.640. The P-value of the F-test is 0.1000 indicating that the F-test is not statistically significant at $5 \%$ level. Hence, the null hypothesis of no autocorrelation is supported and the study concludes that residuals are not auto correlated.

\section{Table 4.6: Heterescadescasity Test}

\section{Breusch-Pagan / Cook-Weisberg test for heteroscedasticity}

Ho: Constant variance

Variables: fitted values of ROA

$\operatorname{chi} 2(1)=156.94$

Prob $>$ chi2 $=0.074$

From the results in Table 4.6 the likelihood-ratio test generated a chi-square value of 156.94 with a p-value of 0.074. The chi-square figure was statistically insignificant at $5 \%$ level and so the null hypothesis of constant variance was accepted justifying the absence of heteroscedasticity in the data as indicated by Poi and Wiggins (2001).

\subsubsection{Hausman Test}

When performing panel data analysis, one has to determine whether to run a random effects model or a fixed effects model (Daly, Dekker \& Hess, 2016). In order to make a decision on the most suitable model to use, both random and fixed effects estimate coefficients. The study used the Hausman's specification test (1978) to choose between fixed and random effect models. In order to select between fixed and random effects model, the Hausman approach was employed as shown in 4.7

Table 4.7: Hausman Random Test for random and fixed effects

\begin{tabular}{llll}
\hline Column1 & $\mathbf{( b )}$ & $\mathbf{( B )}$ & $\mathbf{( b - B )}$ \\
& Fixed & random & Difference \\
\hline Short term debt ratio & 0.049384 & -0.052279 & 0.003562 \\
Long term debt ratio & -0.027458 & -0.028134 & 0.000676 \\
Equity ratio & 0.007855 & 0.007356 & 0.000499 \\
Firm size & -0.058562 & -0.0629822 & 0.00442 \\
ROA & 0.232333 & 0.2389956 & -0.00666 \\
\hline
\end{tabular}

chi2(3) $=(b-B)^{\prime}\left[\left(V_{-} \_-V_{-} \_B\right)^{\wedge}(-1)\right](b-B)=0.26$

Prob $>$ chi $2=0.065$ 
The null hypothesis of the Hausman test was that the random effects model was appropriate compared fixed. The results from Table 4.7 shows that Hausman test indicated $\lambda=0.26$ with a p-value of $0.065>0.05$. The study failed to reject the null hypothesis that random effects model was preferred to fixed model as suggested by Daly, Dekker and Hess (2016). Therefore, random effect model was the appropriate one.

\subsection{Model Regression Analysis}

The study sought to carry out panel regression analysis to establish the statistical significance relationship between the independents variables, short term debt, and long term debt and equity ratio on the dependent variable, profitability measured on return on assets. According to McNeish and Stapleton (2016) regression analysis is a statistical process of estimating the relationship among variables.

It includes many techniques for modeling and analyzing several variables when the focus is on the relationship between a dependent and one or more independent. Table 4.8 presents the panel regression analysis

Table 4.8 Panel Regression Analysis before interaction

\begin{tabular}{|c|c|c|c|c|c|}
\hline ROA & & Coef. & Std. Err. & $\mathbf{z}$ & $\mathbf{P}>|\mathbf{z}|$ \\
\hline Short term debt ratio & & 0.860034 & 0.166894 & 5.15 & 0.000 \\
\hline Long term debt ratio & & -0.12477 & 0.14115 & -0.88 & 0.037 \\
\hline Equity Ratio & & 0.138056 & 0.220155 & 3.81 & 0.000 \\
\hline _constant & & -0.13693 & 0.078697 & -1.74 & 0.082 \\
\hline R squared= & 0.7142 & & & & \\
\hline F statistics $=$ & 111.92 & & & & \\
\hline $\mathrm{P}$ Value $=$ & 0.000 & & & & \\
\hline
\end{tabular}

According to the outcome from table 4.6, the predicted equation is:

$\mathrm{Y}=-0.13693+0.860034 \mathrm{X}_{1}-0.12477+0.138056 \mathrm{X}_{3}$

Where:

$\mathrm{Y}=$ Profitability (ROA)

$\mathrm{X} 1=$ Short term debts

$\mathrm{X} 2=$ Long term debts

$\mathrm{X} 3$ =Equity ratio

As presented in the table 4.8, the regression results found that short term debt ratio, long term debt ratio and equity ratio were established to be satisfactory in predicting the profitability of deposit taking microfinance institutions in Nairobi County. The coefficient of determination R Square was 0.7142. The model indicates that short term debt ratio, long term debt ratio and equity ratio explained $71.42 \%$ of the variation in ROA. This means $71.42 \%$ of the variations in ROA are influenced by financial leverage. The results are in agreement with Ongaki (2012) MFIs institutional manageability is highly determined by its financial performance.

Moreover, the $\mathrm{F}$ value results in Table 4.6 showed that the model was statistically significant. The findings signify that short term debt ratio, long term debt ratio and equity ratio are good predictors of profitability of deposit taking microfinance institutions in Nairobi County. This was supported by F statistics of 111.92 and a P of $0.000<0.05$ level of significance. The results concur with the findings of Rai (2012) who found that performance of financials of microfinance establishments is most likely the key measurement of microfinance manageability and financial Sustainability.

Regression of coefficients findings in Table 4.6 also showed that short term debt was positively and significantly related with return on assets of the deposit taking microfinance in Nairobi $(\beta=0.860034, p=0.000)$. This means that an increase of the short term debts by one unit leads to an increment of the profitability by 0.860034 units holding other factors constant.

The results concur with the findings of Wambua (2018) who found that short term debt and long term debt had a positive and significant association on the financial sustainability of Deposit taking microfinance in Kenya and thus the financial sustainability would increase with a proportionate increase in debt when all other factors affecting the profitability of the organizations are held constant.

Moreover, the results show that long term debt was negatively and significantly related to the profitability (ROA) of the deposit taking microfinances in Nairobi $(\beta-0.12477, \mathrm{p}=0.037)$. This implied that an increase of the long term deposits will lead to a decrease of the profits of the deposit taking microfinances with 0.12477 units holding other factors constant. The results relate with the findings of Kajiriwa (2015) who found that the long-term debt in commercial banks affects the capital structure negatively. High debts become a burden to the firms and the level of the profits is affected negatively. Additionally, equity ratio was found to be positively and significantly related to the profitability of the deposit taking microfinances in Nairobi County $(\beta=0.138056, p=0.000)$. 
The results obtained implied that when the level of the equity increased in the institutions, the profitability of the institutions is going to increase by 0.138056 units holding other factors constant. The results agreed with the findings of Lubawa, Shirima and Nandonde (2018) revealed that equity financing is a relatively cheaper option and as such improves the performance of microfinance institutions.

\subsubsection{Moderation Effect of Firm Size on ROA}

The objective was to establish the moderating effect of firm size on the relationship between leverage and profitability of deposit taking institutions in Nairobi. Each of the independent variables was moderated by the variable firm size. Results after the moderation were presented in Table 4.9

Table 4.9 Moderation Effect of Firm Size Results on ROA for Financial Firms

\begin{tabular}{lllll}
\hline ROA & Coef. & Std. Err. & $\mathrm{z}$ & $\mathrm{P}>|\mathrm{z}|$ \\
\hline Short term debts* log total asset & 0.213783 & 0.059417 & 3.6 & 0.000 \\
Long term debts* log total asset & -0.105436 & 0.046042 & -2.29 & 0.019 \\
Equity ratio* $\log$ total asset & 0.157025 & 0.076191 & 2.06 & 0.039 \\
constant & 0.002217 & 0.075621 & 0.03 & 0.977 \\
\hline
\end{tabular}

R Squared $=0.7662$

F statistics $=132.73$

$P$ value $=0.000$

The model after moderation

$\mathrm{Y}=0.002217+0.213783 \mathrm{X}_{1} * \mathrm{M}-0.0105436 * \mathrm{M}+0.157025 \mathrm{X}_{3} * \mathrm{M}$

Where: $\mathrm{Y}=\mathrm{ROA}$ (Return on Asset)

$\mathrm{X}_{1}=$ Short term debts

$\mathrm{X}_{2}=$ Long term debts

$\mathrm{X}_{3}=$ Equity ratio

$\mathrm{M}=$ Firm Size (Moderator)

The result from Table 4.9 shows that R2 before moderation was $71.42 \%$ but after moderation, the R2 increased significantly to $76.62 \%$. This implied that firm size moderate the relationship between financial leverage and profitability of deposit taking microfinance institutions in Nairobi. The results revealed that the interaction term between short term debt and firm size is positively and significantly related to ROA $(\beta=0.213783, p=0.000)$. This was supported by a calculated t-statistic of 3.6 that is larger than the critical t-statistic of 1.96. Also results revealed that the interaction term between long term debt and firm size is negatively and significantly related to ROA $(\beta=-$ $0.105436, \mathrm{p}=0.019)$.

This was supported by a calculated t-statistic of 2.29 that is larger than the critical t-statistic of 1.96. Likewise, the outcome revealed that the interaction term between equity ratio and firm size is positively and significantly related to ROA ( $\beta=0.157025, p=0.039$ ). This was supported by a calculated $t$-statistic of 2.06 that is larger than the critical t-statistic of 1.96 .

The results corroborate with the results of Bashir and Asad (2018) who showed that firm size of a firm has the potential to influence the firm's financial performance in terms of the choice of capital structure mix and the profitability changes over time depending on the capital structure employed.

\subsection{Conclusion and Recommendations}

The study sought to establish the effect of financial leverage and profitability in deposit-taking microfinance institutions in Nairobi City County, Kenya. The specific objectives that guided the study were the effect of short term debt, long term debt and equity ratio on profitability in deposit-taking microfinance institutions in Nairobi City County. The study also established the moderating effect of firm size on the relationship between financial leverage and profitability. The descriptive research design was utilized to investigate and clarify the present status concerning the objectives of the research. The targeted population was 12 deposit-taking microfinance institutions based in Nairobi City County. The data were analyzed using descriptive and inferential statistics. The coefficient of determination, R squared before moderation was $71.42 \%$, but after moderation, the R2 increased significantly to $76.62 \%$. This implied that the moderation of firm size affected the independent variables, short term debt, and long term debt and equity ratio positively. 


\subsection{Conclusions}

From the findings of the study, the study concludes that short term debt had a positive and significant association on the profitability of the deposit-taking microfinance in Nairobi County. The study also concludes that short term debt has a positive and significant relationship on the profitability of the deposit-taking microfinance in Nairobi County. This means that profitability would increase with a proportionate increase in in the level of the short term debt when all other factors affecting the profitability of the organizations are held constant. The study showed that when the company borrows, availability of sufficient funds to finance the available assets of the company, which in return improves in the level of performance, increases.

The study also concludes that long term debt had a positive and significant correlation on the profitability of the deposit-taking microfinance institutions in Nairobi County. The study further finds that long term debt had a negative and positive relationship on the profitability of the deposit-taking microfinance institutions in Nairobi County. The study showed that long term debt is not favorable to the companies as it attracts higher interest rates that in return, reduce the profitability of the firms.

The study further concludes that equity ratio was positively and significantly correlated to the profitability. Moreover, the equity ratio relates positively and considerably with the profitability level. However, despite the equity capital been important in enhancing the profitability of the deposit-taking microfinance institutions, it is the last financing option for the firms. Finally, it can be concluded that firm size moderates the relationship between financial leverage and profitability among deposit-taking microfinance institutions in Nairobi city county, Kenya. The size of a firm can influence the firm's financial performance in terms of the choice of capital structure mix and the profitability changes over time depending on the capital structure employed.

\subsection{Recommendations}

From the conclusions of the study, the study recommends that short term debt is sufficient and the best option for financing the activities in the deposit-taking micro finances institutions in Nairobi County. The cost of the short term debts is minimal and generally offers lower interest charges, and most lenders do not charge interest until all credit allowance period is breached and therefore becomes useful for companies.

Also, the study recommends that long term debt is not conducive for the financing activities in the process of generation of profits. High levels of the long term debt increase the number of interest payments that are expected to be paid regularly, thus lowering the sustainability of the companies. The companies should only use long term debts if other financing options are not available such as the short term debts.

Additionally, the study recommends that high equity ratio is not suitable for companies. Equity financing positively affects the profitability; nevertheless, it is preferred only when the financing option through short term debts have reached optimal and the company lacks an alternative method to finance its activities.

Finally, the study recommends that deposit-taking institutions increase the number of branches of the institutions. Lenders are much confident to lend out funds to companies that have a larger market share. Larger firms obtain benefits from their size and diversification because they can borrow with lower costs and survive economic disasters with more resilience than smaller firms and thus generate more profit.

\subsection{Suggestions for Further Research}

Apart from short term debt, long term debt, equity ratio liquidity, other indicators are influencing the profitability of the deposit-taking microfinance institutions in Nairobi County. These factors may include regulatory environment, management efficiency and investment growth. Future research should include these variables. The study also relied on ROA as a measure of profitability. Future research should involve measuring profitability using both and Return on Equity (ROE). ROE is an accurate bottom-line profitability metric, comparing the profit available to shareholders to the capital provided or owned by shareholders.

\section{References}

Abiodun, B., Y. (2017). The Effect of Firm Size on Firms Profitability in Nigeria. Journal of Economics and Sustainable Development 4 (5) $102-126$

Abrar, A., \& Javaid, A. Y. (2016). The Impact of capital structure on the profitability of Microfinance institutions. South Asian Journal of Management, 10(1), 21-37.

Abubakar, A. (2015). Relationship between financial leverage and financial performance of deposit money banks in Nigeria. International Journal of Economics, Commerce and Management, 3(10), 759-778.

Adams, R. B., \& Ferreira, D. (2016). Women in the boardroom and their impact on governance and performance. Journal of financial economics, 94(2), 291-309 
Ali, A. E. E. S. (2015). The Regulatory and Supervision Framework of Microfinance in Kenya. International journal of social science 3(9), $123-138$

Allini, A., Rakha, S., McMillan, D. G., \& Caldarelli, A. (2018). Pecking order and market timing theory in emerging markets: The case of Egyptian firms. Research in International Business and Finance, 44, 297308.

Allini, A., Rakha, S., McMillan, D. G., \& Caldarelli, A. (2018). Pecking order and market timing theory in emerging markets: The case of Egyptian firms. Research in International Business and Finance, 44, 297308.

Amsi, F., Ngare, P., Imo, P., \& Gachie, M. (2017). Effect of microfinance credit on SMEs financial performance in Kenya. Journal of Emerging Trends in Economics and Management Sciences, 8(1), 48-61.

Ando, T., \& Bai, J. (2016). Panel data models with grouped factor structure under unknown group membership. Journal of Applied Econometrics, 31(1), 163-191.

Andrew, K. K. (2015). Effect of Corporate Attributes on International Financial Reporting Standards Disclosure Level. Evidence from Kenya Listed Firms. Research Journal of Finance and Accounting Vol, 6, 22221697.

Aro, H., \& Pennanen, T. (2017). Liability-driven investment in longevity risk management. Journal of Optimal Financial Decision 35(3), 121-136.

Ayele, G., T. (2015). Microfinance institutions in Ethiopia, Kenya and Uganda: Loan outreach to the poor and the quest for financial viability. African Development Review, 27(2), 117-129.

Baoko, G., Acheampong, I. A., \& Ibrahim, M. (2017). Determinants of Bank Credit in Ghana: A bounds-testing cointegration approach. African Review of Economics and Finance, 9(1), 33-61.

Barako, D., G., Hancock, P., \& Izan, H. Y. (2016). Factors influencing voluntary corporate disclosure by Kenyan companies. Corporate Governance: an international review, 14(2), 107-125.

Bashir, A., \& Asad, M. (2018). Moderating effect of leverage on the relationship between board size, board meetings and performance: A study on the textile sector of Pakistan. American Scientific Research Journal for Engineering, Technology, and Sciences (ASRJETS), 39(1), 19-29.

Belydah, O. K., \& Herrick, O. (2017). Determinants of the financial performance of deposit-taking microfinance institutions and co-operative societies that have front office service activities registered with sasra. International Journal of Finance and Accounting, 1(3), 118-138.

Bendavid, I., Herer, Y. T., \& Yücesan, E. (2017). Inventory management under working capital constraints. Journal of Simulation, 11(1), 62-74.

Bhama, V., Jain, P. K., \& Yadav, S. S (2016). Testing the pecking order theory of deficit and surplus firms: Indian evidence. International Journal of Managerial Finance, 12(3), 335-350.

Bhardwaj, A. (2018). Financial Leverage and Firm's Value: A study of capital Structure of Selected Manufacturing Sector Firms in India. Journal of financial management 44(9), $166-184$

Bhuiyan, M. B. U., \& Roudaki, J. (2018). Related party transactions and finance company failure: New Zealand evidence. Pacific Accounting Review, 30(2), 199-221.

Bhushan S., \& Mohinder S. (2016). Impact of Capital Structure on Firm's Profitability: A Study of selected listed Cement Companies in India. pacific business review international,8(7), 46-54

Boadi, I., Dana, L. P., Mertens, G., \& Mensah, L. (2017). SMEs' financing and banks' profitability: a "good date" for banks in Ghana? Journal of African Business, 18(2), 257-277.

Boddy, C. R. (2016). Sample size for qualitative research. Qualitative Market Research: An International Journal, $19(4), 426-432$.

Born, B., \& Breitung, J. (2016). Testing for serial correlation in fixed-effects panel data models. Econometric Reviews, 35(7), 1290-1316.

Bosse, D. A., \& Phillips, R. A. (2016). Agency theory and bounded self-interest. Academy of Management Review, 41(2), 276-297.

CBK. (2018). Annual financial supervision report. Nairobi: Central Bank of Kenya.

Chadha, S., \& Sharma, A. K. (2015). Capital Structure and Firm Performance: Empirical Evidence from India. Vision: The Journal of Business Perspective, 19(4), 295-302.

Charness, G., \& Neugebauer, T. (2019). A Test of the Modigliani-Miller Invariance Theorem and Arbitrage in Experimental Asset Markets. The Journal of Finance, 74(1), 493-529.

Chavali, K., \& Rosario, S. (2018). Relationship between Capital Structure and Profitability: A Study of NonBanking Finance Companies in India. Academy of Accounting and Financial Studies Journal, 22(1), 1-8.

Chen, Z., Harford, J., \& Kamara, A. (2019). Operating Leverage, Profitability, and Capital Structure. Journal of Financial and Quantitative Analysis, 54(1), 369-392.

Chesang, D. (2017). Effect of financial leverage on profitability of listed agricultural firms at the Nairobi securities exchange (Doctoral dissertation, Kisii university).

Chikalipah, S. (2018). Do microsavings stimulate financial performance of microfinance institutions in SubSaharan Africa? Journal of Economic Studies, 45(5), 1072-1087. 
Cole, C., Yan, Y., \&Hemley, D. (2015). Does Capital Structure Impact Firm Performance: An Empirical Study of Three US Sectors. The Journal of Accounting and Finance, 15(6), 57-65

Colorafi, K. J., \& Evans, B. (2016). Qualitative descriptive methods in health science research. Health Environments Research \& Design Journal, 9(4), 16-25.

Daly, A., Dekker, T., \& Hess, S. (2016). Dummy coding vs effects coding for categorical variables: Clarifications and extensions. Journal of choice modelling, 21(6), 36-41.

Das, C. P., \& Swain, R. K. (2018). Influence of Capital Structure on Financial Performance. Parikalpana-KIIT Journal of Management, 14(1), 161-170.

Das, K. R., \& Imon, A. H. M. R. (2016). A brief review of tests for normality. American Journal of Theoretical and Applied Statistics, 5(1), 5-12.

Dombret, A., Gündüz, Y., \& Rocholl, J. (2019). Will German banks earn their cost of capital? Contemporary Economic Policy, 37(1), 156-169.

Godswill, O., Ailemen, I., \& Osabohien, R. (2018). Working capital management and bank performance: Empirical research of ten deposit money banks in Nigeria. Banks and Bank Systems, 13(2), 49-61.

Gong, D., Tang, M., Liu, S., \& Li, Q. (2017). Reconsidering production coordination: A principal-agent theorybased analysis. Advances in Production Engineering \& Management, 12(1), 51-61.

Graham, J. R., Harvey, C. R., \& Puri, M. (2017). Managerial attitudes and corporate actions. Journal of financial economics, 109(1), 103-121.

Greenwood, M. (2016). Approving or improving research ethics in management journals. Journal of Business Ethics, 137(3), 507-520.

Gudeta, S. (2013). Determinants of profitability: An empirical study on Ethiopian Microfinance Institutions. (Unpublished MSc project Addis Ababa University, Addis Ababa, Ethiopia).

Harford, J., Kecskés, A., \& Mansi, S. (2018). Do long-term investors improve corporate decision making? Journal of Corporate Finance, 50, 424-452.

Hossain \& Azam (2016). Determinants Financial Sustainability of Microfinance Institutions (MFIs) of Bangladesh. Developing Country Studies, Vol 6 No. 6,

Jeleel, A., \& Olayiwola, B. (2017). Effect of leverage on firm performance in Nigeria: A case of listed chemicals and paints firms in Nigeria. Global Journal of Management and Business Research.

Kajiriwa, H.I. (2015). Effect of debt on firm performance: A survey of commercial banks listed on Nairobi Securities Exchange. Global Journal of Advanced Research, 2(6), 1025-1029

Kalu, E. O., Shieler, B., \& Amu, C. U. (2018). Credit risk management and financial performance of microfinance institutions in Kampala, Uganda. Independent journal of management \& production, 9(1), 153-169. 